\title{
ANALISA DATA VIBRASI UNTUK MENGIDENTIFIKASI KONDISI DAN SYMTOM PADA KOMPRESOR TURBIN GAS SIEMENS V 94.2 PEMBANGKIT LISTRIK TENAGA UAP
}

\author{
Gary Liadi $^{1^{*}}$, Ikhwansyah Isranuri ${ }^{2}$, M. Sabri ${ }^{3}$, Marragi M ${ }^{4}$, Dian M. Nasution ${ }^{5}$ \\ ${ }^{1,2,3,4,5}$ Departemen Teknik Mesin, Fakultas Teknik, Universitas Sumatera Utara \\ Email: garyyliadi30@gmail.com
}

\begin{abstract}
Along with the times, the population is increasing which means there is also an increasing need for electrical energy. One solution to this problem is to build powerplant as a large-scale provider of electrical energy. In this state-wide energy supply company, maintenance is needed to guarantee the production quality of the company. Maintenance plays an important role in the production activities of a company that concerns the smoothness or congestion of production, production volume, and so that the output produced is well received by consumers. Based on the data analysis, it can be concluded that in the time domain it can be seen that the highest vibration at measuring point 2 is located in the horizontal direction while the highest vibration at measuring point 3 is in the axial direction. In the frequency domain, it can be seen the phenomenon of unbalance symptoms and misalignment on the turbine shaft point 2 and 3. From the calculation results also obtained that the results of compliance (-2,57764 x 10-9), mobility $(1,66058 \times 10-6)$ and inertance $(0,000562006)$.
\end{abstract}

Keywords: symtoms, Fast Fourier Transform, vibration

\begin{abstract}
Abstrak
Seiring perkembangan zaman, jumlah penduduk semakin bertambah yang berarti semakin bertambah pula kebutuhan akan energy listrik. Salah satu solusi untuk permasalahan tersebut yaitu dengan membangun pembangkit listrik sebagai penyedia energi listrik skala besar. Dalam perusahaan penyedia energi berskala negara ini, pemeliharaan sangat dibutuhkan untuk menjamin kualitas produksi dari perusahan tersebut. Pemeliharaan (maintenance) berperan penting dalam kegiatan produksi dari suatu perusahaan yang menyangkut kelancaran atau kemacetan produksi, volume produksi, serta agar output yang diproduksi diterima konsumen dengan baik. Penelitian ini bertujuan untuk mengetahui masalah yang ditimbulkan oleh salah satu turbin uap yang ada pada pembangkit listrik. Metode yang digunakan dalam penelitian ini adalah dengan menganalisa dan memproyeksikan data vibrasi dengan metode Fast Fourier Transform.Berdasarkan analisa data yang dilakukan, diperoleh kesimpulan bahwa dalam time domain dapat dilihat bahwa vibrasi tertinggi pada titik ukur 2 terletak pada arah horizontal sedangkan vibrasi tertinggi pada titik ukur 3 terdapat pada arah aksial. Pada frequency domain, dapat dilihat adanya fenomena gejala unbalance serta misalignment pada poros turbin titik 2 dan 3. Dari hasil perhitungan didapat juga bahwa hasil dari compliance (-2,57764 x 10-9), mobility (1,66058 x 10-6) dan inertance $(0,000562006)$.
\end{abstract}

Kata kunci : symtom, Fast Fourier Transform, vibrasi

\section{PENDAHULUAN}

Sebagai salah satu negara dengan populasi terbesar ke-4 dunia, Indonesia harus bisa dengan cermat memenuhi kebutuhan akan energi listrik. Salah satu caranya yaitu dengan membangun Pembangkit Listrik Negara (PLN). Namun, untuk dapat memenuhi kebutuhan 
listrik negara, PLN juga harus dengan cermat memantau kondisi dari alat pembangkit listrik yang dalam hal ini adalah turbin uap. Hal ini dapat dilakukan dengan cara menganalisa vibrasi dari poros turbin uap yang beroperasi dan mengetahui fenomena apa yang ada pada turbin uap terutama dalam poros kompresor.

\section{TEORI DASAR}

\subsection{Kompresor}

Kompresor merupakan suatu alat mekanik yang berfungsi untuk meningkatkan tekanan fluida mampu mampat, yaitu gas atau udara. Adapun tujuan dari peningkatkan tekanan adalah untuk menghasilkan kebutuhan tekanan dalam suatu sistem proses yang lebih besar (dapat berupa sistem fisika maupun kimia seperti pengaplikasian kompresor pada turbin di pembangkit listrik).

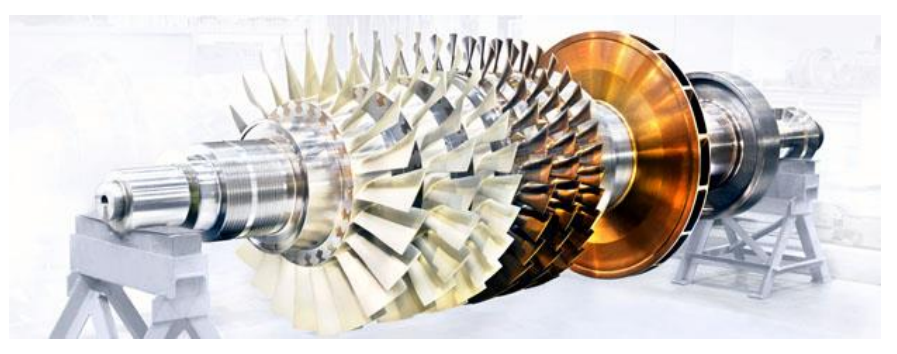

Gambar 2.1 Kompresor

\subsection{Vibrasi Pada Kompresor}

Dalam kompresor, bagaimanapun, penyebab paling umum adalah ketidakseimbangan pada bagian yang berputar dan gaya aerodinamik yang abnormal. Penyebab umum untuk getaran tinggi adalah bantalan yang buruk. Jika bantalan keluar, itu tidak melakukan tugas yang diperlukan dan pada akhirnya perlu diganti. Penyebab umum lainnya untuk getaran tinggi adalah pengencang mekanis yang terlepas atau tidak tepat. Unbalance adalah terjadinya pergeseran titik pusat massa dari titik pusat putarnya sehingga akan menimbulkan getaran yang tinggi. Besarnya amplitudo getaran sebanding dengan besarnya putaran (merupakan kuadrat dari putaranya).

\subsection{Time Domain dan Frequency Domain}

Time domain mengacu pada analisis fungsi matematika, sinyal fisik atau deret data (dalam hal ini vibrasi), sehubungan dengan waktu . Dalam domain waktu, nilai sinyal atau fungsi diketahui untuk semua bilangan real, untuk kasus waktu kontinu, atau pada berbagai contoh terpisah seperti dalam kasus waktu

Domain frekuensi mengacu pada analisis fungsi atau sinyal matematika sehubungan dengan frekuensi, bukan waktu. Sederhananya, grafik domain-waktu menunjukkan bagaimana suatu sinyal berubah dari waktu ke waktu, sedangkan grafik domain frekuensi menunjukkan seberapa banyak sinyal terletak di dalam setiap pita frekuensi yang diberikan pada rentang frekuensi. 

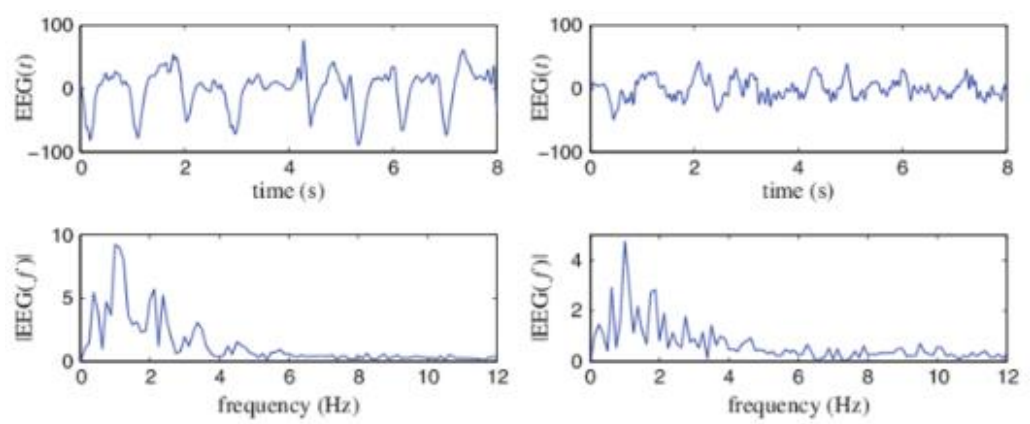

Gambar 2.2 Time Domain dan Frequency Domain

\subsection{Compliance, Mobility dan Intertance}

Compliance secara umum merupakan ukuran berapa banyak struktur bergerak (perpindahan, $\mathrm{x}$ ) untuk satuan input gaya (F). Kekakuan, atau ketahanan terhadap deformasi dari gaya input, sangat penting dalam dinamika struktural dan topik terkait kebisingan dan getaran. Getaran dapat dianggap sebagai rasio gaya yang bekerja pada struktur dengan kekakuannya. Intertance atau yang sering disebut dengan innertance merupakan perbandingan antara percepatan dan gaya. Mobility adalah salah satu parameter dari fungsi Frequency Response Function (FRF). Grafik umum. asymtote yang mendahului frekuensi alami meningkat secara linear seiring dengan frekuensi dan berbanding terbalik dengan nilai kekakuan. Kemiringan dari asymptote yang menggantikan frekuensi alami berkurang dengan frekuensi dan berbanding terbalik dengan massa.

\subsection{Fast Fourier Transform}

Fourier Analisis adalah proses matematika yang digunakan untuk memecahkan masalah bentuk gelombang kompleks dengan menguraikan gelombang itu menjadi komponen sinusoidanya melalui proses transformasi gelombang fungsi waktu menjadi fungsi frekuensi. Metode yang banyak digunakan untuk proses transformasi ini adalah Fast Fourier Transform (FFT).

Spektrum getaran FFT merupakanmetode yang sangat berguna untuk analisis getaran mesin. Jika ada masalah mesin, spektrum FFT memberikan informasi untuk membantu menentukan sumber dan penyebab masalah dan, dengan tren, berapa lama hingga masalahnya menjadi kritis.Spektrum FFT memungkinkan untuk menganalisis amplitudo getaran pada berbagai frekuensi komponen pada spektrum FFT. Dengan cara ini, dapat mengidentifikasi dan melacak getaran yang terjadi pada frekuensi tertentu. Karena masalah mesin tertentu menghasilkan getaran pada frekuensi tertentu, maka informasi ini dapat digunakan untuk mendiagnosis penyebab getaran berlebihan yang ada.

\section{HASIL DAN PEMBAHASAN}

\subsection{Data Vibrasi Mainshaft Kompresor}

Dalam analisa data poros kompresor, data pada titik 2 dan 3 ditinjau karena merupakan poros penghubung pada kedua ujung kompresor .Peninjauan data dilakukan untuk mendapatkan grafik time domain dan juga frequency domain dengan menggunakan Fast Fourier Transform. 


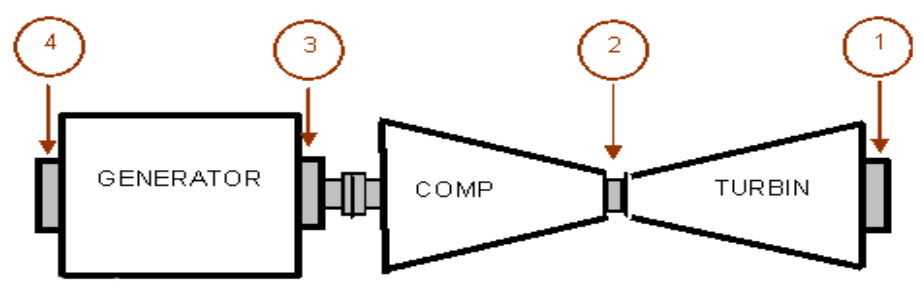

Gambar 3.1 Titik Ukur Vibrasi Turbin

Adapun data yang ditinjau berupa data vibrasi dalam $\mathrm{mm} / \mathrm{sec}$. Data vibrasi yang ditinjau memiliki 3 arah ukur yang bervariasi yaitu dalam arah horizontal, arah vertikal, dan juga arah aksial.

Tabel 3.1 Data Vibrasi Poros Titik Ukur Kompresor

\begin{tabular}{|c|c|c|c|c|c|c|c|}
\hline \multicolumn{8}{|l|}{ oAta vean } \\
\hline \multicolumn{2}{|c|}{ NOUCR PENGUKUTN } & \multicolumn{3}{|c|}{2} & \multicolumn{3}{|c|}{2} \\
\hline \multicolumn{2}{|c|}{ SUUBU PEVGUKURN } & M02 & ver & $A 02$ & Hod & ves & $A 06$ \\
\hline & BATUN & mmsec & mmsec & mmses & mises & mises & mmise \\
\hline & NDown & \multicolumn{6}{|c|}{ NOT AVAILABLE } \\
\hline It Fenuar 2004 & OATA & 6 & 7,1 & 4.8 & 2,4 & 6.2 & 125 \\
\hline 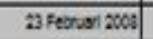 & DATA & 6,4 & 6,8 & 4,8 & 2,4 & 6,6 & 18,4 \\
\hline 99 Non 2064 & OATA & 6.6 & 0,4 & 2.7 & $2, t$ & 27 & 10.5 \\
\hline 11 Aoni 2008 & DATA & 6,8 & 0.8 & 2,2 & 4 & 8,4 & 20,7 \\
\hline DI Hel 2000 & OATA & 6,7 & 0,1 & 24 & 2.6 & 7,7 & 10.2 \\
\hline O6 AOI 2010 & DATA & 14,8 & 8.8 & 2.7 & 6.2 & 8.8 & 2 \\
\hline 1: Oesses 2010 & DATA & 16,1 & 2,7 & 4,1 & 6,2 & 7 & 2.2 \\
\hline zatonl 2010 & DATA & 17,65 & 10,02 & 6.2 & 2,8 & 12,4 & 16,2 \\
\hline 07 Sephemoer 2016 & DATA & 18,48 & 11,21 & 4,81 & 8,83 & 13,18 & $10,8 s$ \\
\hline Al Sesterse 2010 & DATA & 17,8 & 10,8 & 6,12 & 2,44 & 11,76 & 10,12 \\
\hline 12 Ottoce 2010 & OATA & 17,68 & 10,02 & 6,24 & 8,83 & 12,44 & 14,24 \\
\hline 19 Coscet 2016 & OATA & 17,76 & 0.64 & ets & 0,10 & 12,41 & 12,40 \\
\hline 25 Oecobe 2010 & DATA & 18,82 & 0.88 & 6,004 & 8.28 & 11,64 & 11,76 \\
\hline Q2 Nosentise 2010 & OATA & 17,44 & 0.25 & 6,25 & 0.04 & 13,13 & 11,49 \\
\hline C9 Nogenter 2010 & DATA & 18,28 & 8,04 & 6,70 & 8,16 & 12,85 & 11,61 \\
\hline Of Destroes 210 & OATA & 14,65 & 11,28 & 6,46 & 4,48 & 6.27 & 1,81 \\
\hline 10 He: 2011 & DATA & 12,4 & 10,22 & 4,4 & 8 & 10,44 & 10.06 \\
\hline 2ullei 2011 & OATA & 12,07 & 10,74 & 4,24 & 6,02 & 8,10 & 8,72 \\
\hline 16 Jal Sen1 & OATA & 12,28 & 11,22 & 6,14 & $6 n$ & 10,02 & 12,25 \\
\hline As vanl 2011 & DATA & 10,89 & 11,81 & 6,4 & 6.24 & 10,18 & 10,41 \\
\hline 12 wat 2011 & DATA & 13,24 & 11,69 & 6,45 & 4,4 & 0,10 & 12,12 \\
\hline 27042011 & DATA & 13,27 & 10,64 & 4,14 & 6,84 & 8.80 & 10.21 \\
\hline 69 Nusas 2011 & OATA & 12,6 & 11,24 & 6 & 6,71 & 10,45 & 12,16 \\
\hline DNos:S 2011 & DATA & 12,70 & 11,04 & 4.8 & 6.70 & 10,28 & 10,8 \\
\hline 06 Segrance 2011 & OATA & 11,88 & 11,08 & 6,07 & 6,76 & 10,87 & 8.11 \\
\hline 20 Sestarce 3011 & OATA & 11,76 & 11 & 4,64 & 6,40 & 0.64 & $0 . n$ \\
\hline C4 Ocobes 2011 & DATA & 14,24 & 11,11 & 4,12 & 6,61 & 11,65 & 8,72 \\
\hline 11 Coses 2011 & OATA & 14,05 & 10,44 & 6,01 & 6.9 & 0,87 & 11,19 \\
\hline zr Nogence 2011 & DATA & 13,84 & 10,89 & 4,22 & 4,86 & 8.24 & 8.04 \\
\hline 07 Desserse :511 & DATA & 14,82 & $10, n 2$ & 4,77 & 6,41 & 0,24 & 2.196 \\
\hline Zn Desembe 2:11 & DATA & 13,74 & 10,28 & 4,8 & 6.28 & 9.69 & 10,49 \\
\hline O4 Janvar 201: & OATA & $12,8 s$ & 11,44 & 6,74 & 6,87 & 10,23 & 10,68 \\
\hline
\end{tabular}




\subsection{Time Domain}

Berikut merupakan time domain dari mainshaft pada titik 2 dan titik 3:

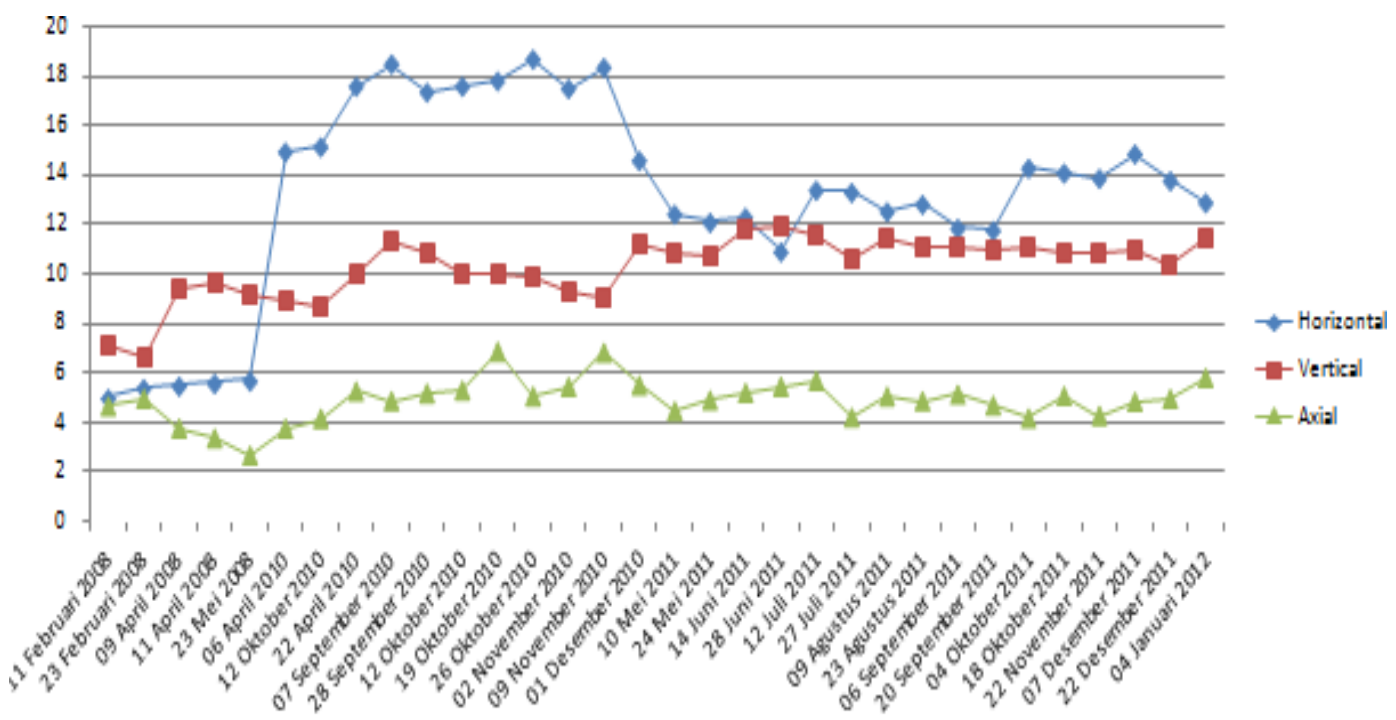

\section{Gambar 3.2 Time Domain Titik 2}

Pada time domain dapat dilihat bahwa vibrasi tertinggi pada titik ukur 2 terletak pada arah horizontal sedangkan vibrasi tertinggi pada titik ukur 3 terdapat pada arah aksial.



Gambar 3.3 Time Domain Titik 3

\subsection{Analisa Frequency Domain Arah Horizontal}

Dari data vibrasi Horizontal pada titik 2 dan titik 3, dilakukan Fourier Analysis pada perangkat lunak Microsoft Excel. 
Dari pengolahan data FFT data vibrasi ,maka didapat grafik spectrum vibrasi poros kompresor titik 2 dan 3 pada arah horizontal.

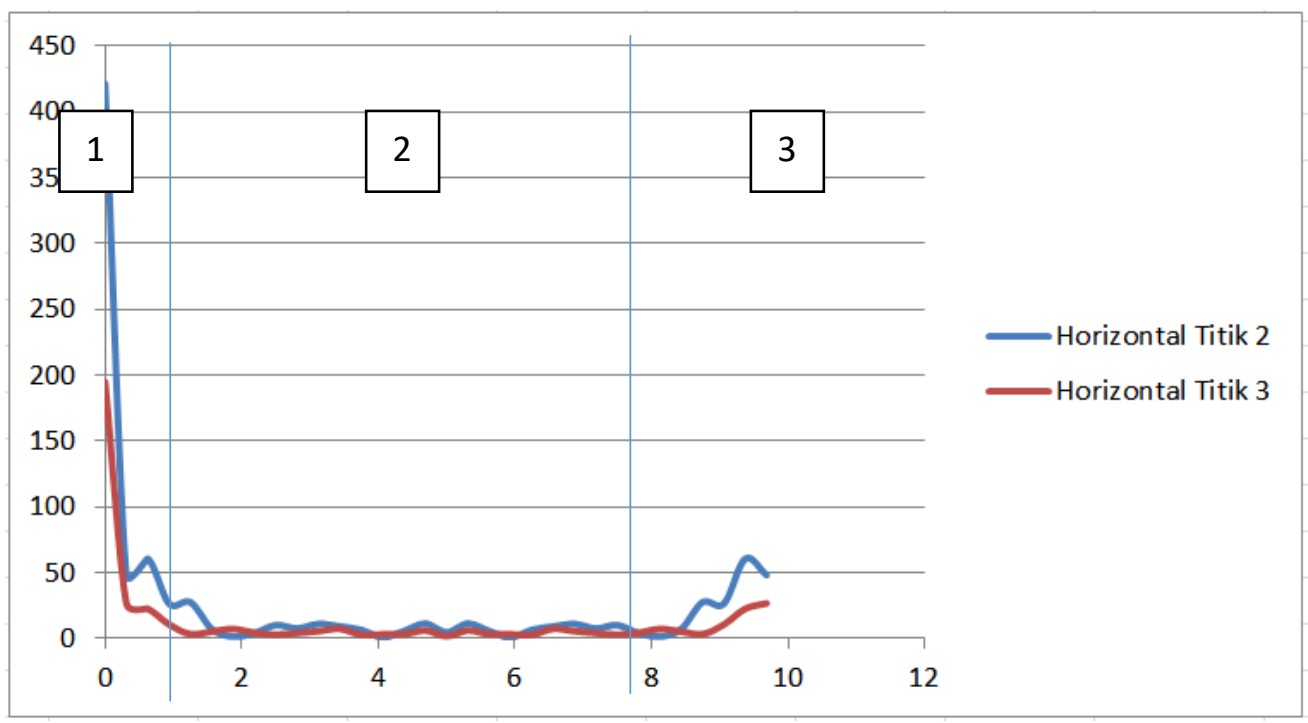

Gambar 3.4 Frequency Domain Horizontal Titik 2 dan 3

Pada grafik spectrum diatas dapat dilihat adanya symptom unbalance pada grafik horizontal titik 2 dan juga symptom unbalance yang mengarah kepada misalignment pada grafik horizontal titik 3.

Pada grafik horizontal titik 2 dapat dilihat adanya first harmonic pada frekuensi 0,4 sedangkan pada grafik horizontal titik 3 tidak ada first harmonic.

Pada grafik potongan ke 2 ini dapat dilihat adanya getaran agak tinggi dari turbin (titik 2 ) dan juga getaran tersebut dapat dikatakan hampir periodic, sedangkan pada grafik merah (titik 3), terlihat adanya getaran vibrasi yang tidak beraturan dari generator, jika kondisi generator bagus, biasanya vibrasi yang dihasilkan lebih beraturan. Akan tetapi vibrasi yang dihasilkan pada titik 3 masih dalam kondisi yang tidak kritis atau layak beroperasi.

Pada potongan ketiga grafik horizontal ini dapat dilihat adanya symptom atau gejala arus balik atau reverser power dari generator. Reverse power merupakan aliran daya listrik dengan arah yang berlawanan dari seharusnya pada generator yang bermasalah. Daya listrik yang dating dari arah yang berlawanan menyebabkan generator yang menerima menghasilkan vibrasi yang lebih tinggi.

\subsection{Analisa Frequency Domain Arah Vertikal}

Dari pengolahan data vibrasi dengan FFT, didapat grafik spectrum vibrasi poros kompresor titik 2 dan 3 pada arah vertical. 




Gambar 3.5 Frequency Domain Vertikal Titik 2 dan 3

Pada grafik spectrum diatas dapat dilihat adanya symptom unbalance pada grafik horizontal titik 2 dan juga symptom unbalance yang mengarah kepada misalignment pada grafik horizontal titik 3.

Dalam grafik sebelumnya dapat dilihat adanya symptom atau gejala looseness pada grafik vertical titik 2 dan juga adanya symtom bearing defect pada grafik vertical titik 3 dengan peak spectrum pada frekuensi 2 dan juga 8 .

\subsection{Analisa Frequency Domain Arah Aksial}

Dari pengolahan data vibrasi FFT, didapat grafik spectrum vibrasi poros kompresor titik 2 dan 3 pada arah aksial.

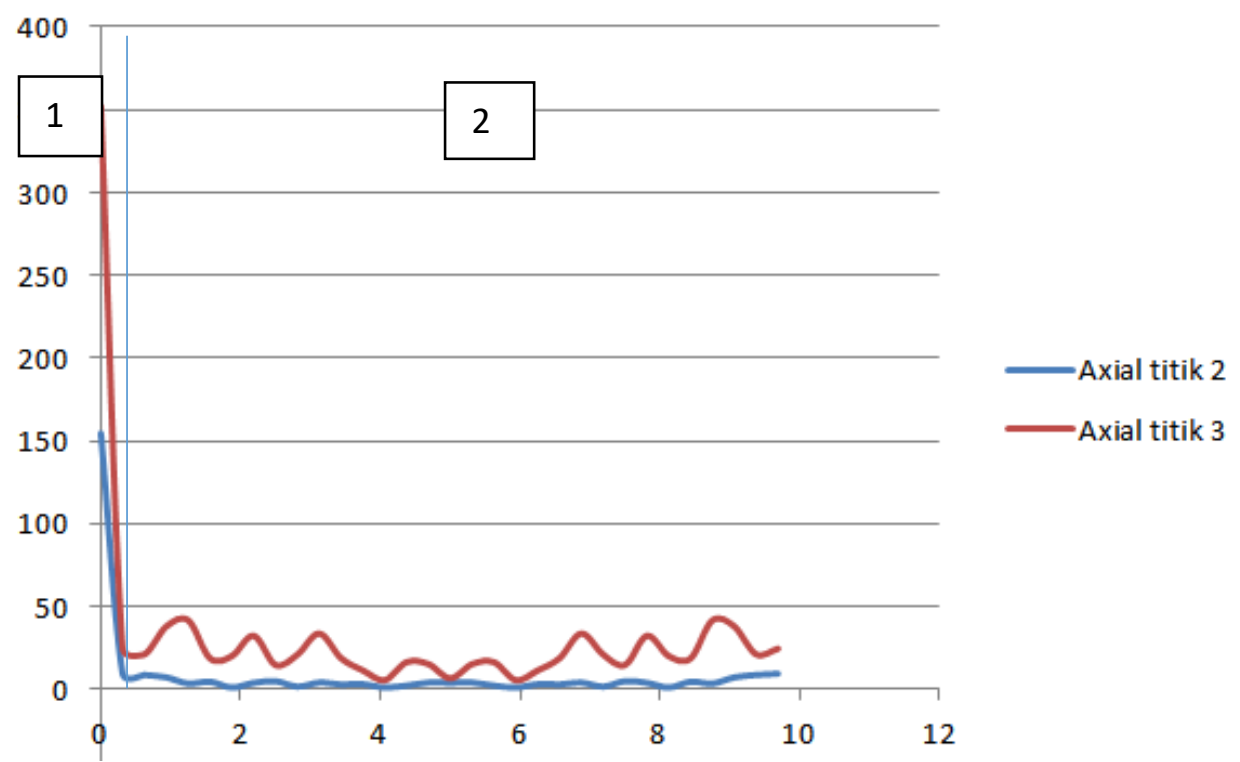

Gambar 3.6 Frequency Domain Aksial Titik 2 dan 3 
Pada grafik spectrum diatas dapat dilihat adanya symptom unbalance pada grafik horizontal titik 2 dan juga symptom unbalance yang mengarah kepada misalignment pada grafik horizontal titik 3.

Dalam grafik bagian 2 dapat dilihat adanya symptom atau gejala looseness pada grafik vertical titik 2 dan juga adanya symtom bearing defect pada grafik vertical titik 3 .

\subsection{Perhitungan Compliance, Mobility dan Inertance}

Setelah melakukan analisa fenomena pada poros kompresor, maka selanjutnya dilakukan analisa perhitungan terhadap compliance, mobility dan inertance daripada poros kompresor.

\subsubsection{Hasil Compliance}

Dari fungsi awal domain waktu yang merupakan Acos $\omega t$, dapat didapatkan fungsi awal simpangan dengan mengintegralkan fungsi awal Acos $\omega \mathrm{t}$.

Sehingga fungsi awal dari simpangan (displacement) merupakan :

$$
\frac{A}{\omega} \sin \omega \mathrm{t}
$$

Dimana :

A $=$ Amplitudo

$\omega=$ Kecepatan sudut $(312.74 \mathrm{rad} / \mathrm{s})$

$\mathrm{t}=$ Waktu $(\mathrm{s})$

Dari fungsi awal simpangan (displacement) dibuat grafik berdasarkan fungsi tersebut secara horizontal, vertical, dan aksial. Dan dari ketiga fungsi tersebut dapat digabung menjadi 1 fungsi regresi yang digunakan untuk menghitung compliance dari poros turbin titik 3 .

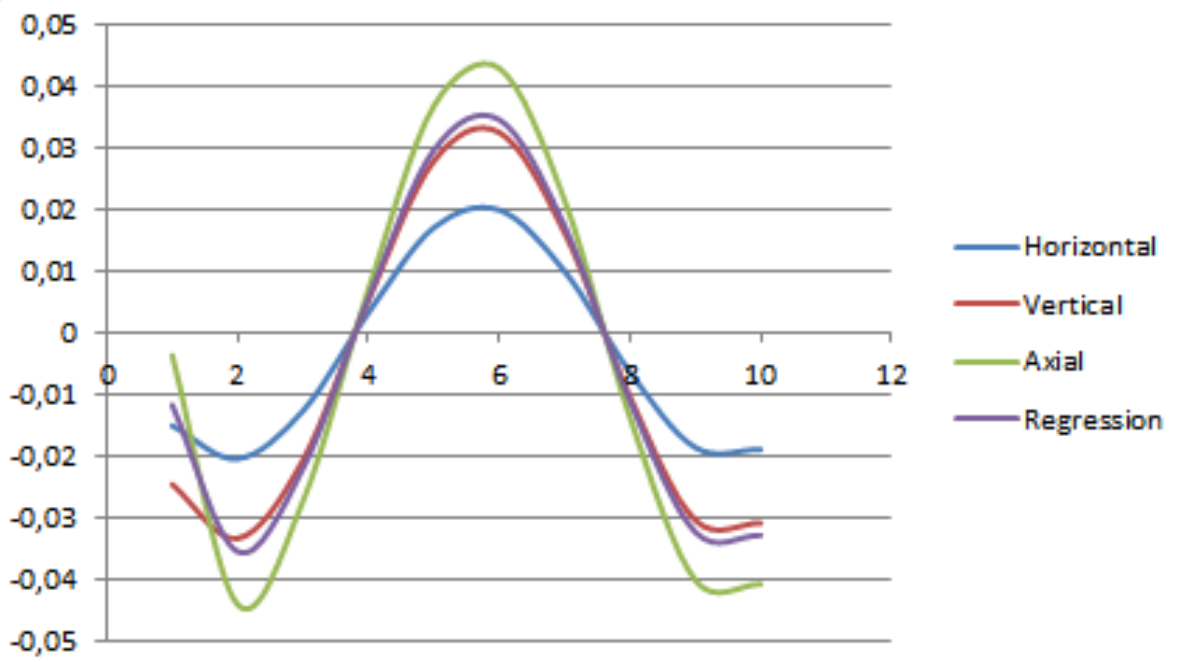

Gambar 3.7 Grafik Fungsi Compliance

Dari grafik regresi, maka didapatlah fungsi regresi simpangan yaitu :

$$
\frac{4,99}{\omega} \sin \omega \mathrm{t}
$$

Danm kemudian dapat dihitung simpangan regresi dengan hasil : -0,01174

Dari hasil simpangan regresi, dapat dihitung Compliance dengan menggunakan rumus :

$$
\text { Compliance }=\text { Displacement } / \text { Force } \text {. }
$$


Dengan demikian maka didapat harga dari compliance sebesar $-\mathbf{2 , 5 7 7 6 4} \times \mathbf{1 0}^{-9}$

\subsection{2}

\section{Hasil Mobility}

Dari fungsi awal kecepatan (velocity), yang merupakan Acos $\omega t$, dibentuklah grafik berdasarkan fungsi tersebut secara horizontal, vertikal, dan aksial. Dan dari ketiga fungsi tersebut dapat digabung menjadi 1 fungsi regresi yang digunakan untuk menghitung mobility dari poros turbin titik 3 .

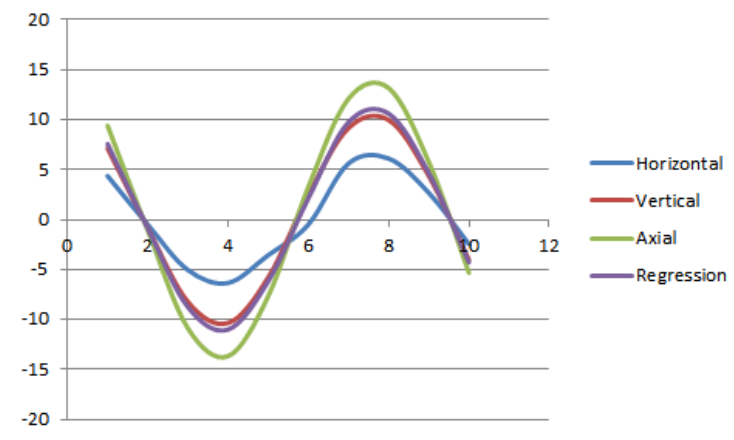

Gambar 3.8 Grafik Fungsi Mobility

Dari grafik regresi, maka didapatlah fungsi regresi kecepatan yaitu :

$$
11,143 \cos \omega \mathrm{t}
$$

Maka didapatlah kecepatan regresi dengan hasil : 7,563805812

Dari hasil kecepatan regresi, dapat dihitung Mobility dengan menggunakan rumus ():

$$
\text { Mobility }=\text { Velocity } / \text { Force } \text {. }
$$

Dengan demikian maka didapat harga dari mobility sebesar $1,66058 \times 10^{-6}$

\subsubsection{Hasil Inertance}

Dari fungsi awal percepatan (acceleration), yang merupakan A $\omega$ sin $\omega \mathrm{t}$, dibentuklah grafik fungsi tersebut secara horizontal, vertikal, dan aksial. Dan dari ketiga fungsi tersebut dapat digabung menjadi 1 fungsi regresi yang digunakan untuk menghitung Inertance dari poros turbin titik 3.

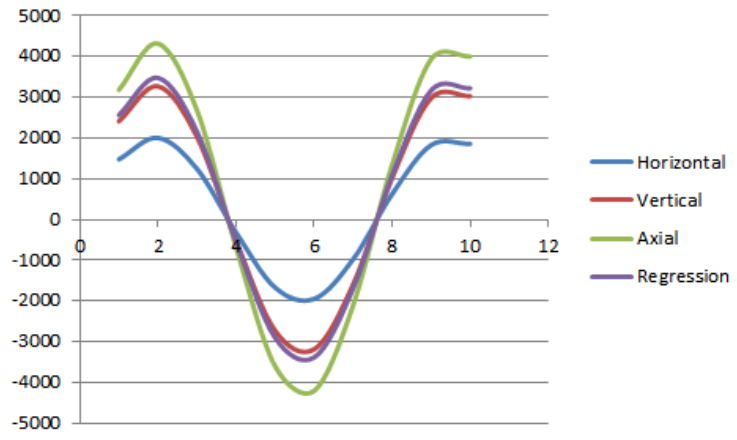

Gambar 3.9 Grafik Fungsi Inertance

Dari grafik regresi, maka didapatlah fungsi regresi percepatan yaitu :

$-11,14 \omega \sin \omega t$ 
Maka didapatlah percepatan regresi dengan hasil : 2559,884678

Dari hasil percepatan regresi, dapat dihitung inertance dengan menggunakan rumus :

$$
\text { Inertance }=\text { Acceleration } / \text { Force } .
$$

Dengan demikian maka didapat harga dari inertance sebesar $\mathbf{0 , 0 0 0 5 6 2 0 0 6}$

\section{KESIMPULAN DAN SARAN}

\subsection{Kesimpulan}

Adapun kesimpulan dari penelitian ini adalah sebagai berikut :

1. Pada time domain dapat dilihat bahwa vibrasi tertinggi pada titik ukur 2 terletak pada arah horizontal sedangkan vibrasi tertinggi pada titik ukur 3 terdapat pada arah aksial.

2. Pada frequency domain, dapat dilihat adanya fenomena gejala unbalance serta misalignment pada poros turbin titik 2 dan 3.

3. Adapun hasil dari compliance $-\mathbf{2 , 5 7 7 6 4} \times \mathbf{1 0}^{-9}$, mobility $1,66058 \times 10^{-6}$ dan inertance 0,000562006 .

\subsection{Saran}

Adapun saran untuk penelitian yang lebih bagus kedepannya adalah sebagai berikut:

1. Disarankan ada penelitian lebih lanjut mengenai frequency domain horizontal titik 3 yang menunjukkan adanya kenaikan spectrum.

2. Disarankan adanya kajian lanjutan pada compliance, mobility, serta inertance pada poros kompresor secara simulasi dan teoritis.

3. Sebaiknya ada dilakukan simulasi lebih lanjut dengan menggunakan ANSYS pada poros titik ukur kompresor, turbin dan generator

\section{REFERENSI}

Mais, Jason "Spectrum Analysis" (Online) https://www.skf.com/binary/tcm:12113997/CM5118\%20EN\%20Spectrum\%20Analysis.pdf (diakses 28 Juni 2019)

Klingenberg, Larry "Frequency Domain Using Excel" (Online) http://www.stem2.org/je/Excel_FFT_Instructions.pdf (diakses 2 Juli 2019)

Kerr, Douglas A "The Fourier Analysis Tool in Microsoft Excel" (Online) http://dougkerr.net/Pumpkin/articles/Excel_Fourier.pdf (diakses 2 Juli 2019)

Aref, Mohamad "Fast Fourier Transformation of Vibration Signals using Microsoft EXCEL"(Online)https://math.arizona.edu/ atpmena/conference/proceedings/Mohamme d_Aref.doc (diakses 8 Juli 2019) 